\title{
Nested identities as cognitive drivers of strategy
}

\section{Authors: Jennifer Irwin, Brooke Lahneman, and Anne Parmgiani}

This is the peer reviewed version of the following article: see citation below, which has been published in Strategic Management Journal and found in final form at https://dx.doi.org/10.1002/ smi.2735. This article may be used for non-commercial purposes in accordance with Wiley Terms and Conditions for Self-Archiving.

Irwin, Jennifer, Brooke Lahneman, and Anne Parmigiani. "Nested identities as cognitive drivers of strategy." Strategic Management Journal 39, no. 2 (December 2017): 269-294. DOI: 10.1002/ smj.2735.

Made available through Montana State University's $\underline{\text { ScholarWorks }}$ 


\title{
Nested identities as cognitive drivers of strategy
}

\author{
Jennifer $\operatorname{Irwin}^{1}$ | Brooke Lahneman ${ }^{2}$ | Anne Parmigiani ${ }^{3}$ \\ ${ }^{1}$ Lycoming College, Williamsport, Pennsylvania \\ ${ }^{2}$ Jake Jabs College of Business and \\ Entrepreneurship, Montana State University, \\ Bozeman, Montana \\ ${ }^{3}$ Lundquist College of Business, University of \\ Oregon, Eugene, Oregon
}

Research Summary: Organizations face tensions to con-form to industry norms for legitimacy yet differentiate for competitive advantage when implementing strategies. We suggest this tension is due to and resolved through orga-nizations' cognitive negotiations of multiple levels of identity. Through an inductive study in the recreational vehicle industry, we find that organizations concurrently draw on identities at the organizational, industry, and strategic group levels to formulate and enact specific competitive actions. Specifically, we find that organiza-tional identity relates to decisions on product offerings; industry identity relates to downstream strategy; and stra-tegic group identity relates to upstream strategy, firm boundaries, and expansion mode. Our findings highlight the importance of strategic group identity and inform a grounded model describing how organizations draw upon different levels of identity to influence strategy.

Managerial Summary: Many managers experience ten-sions of differentiating their firms' competitive actions from rivals, while conforming with industry norms and practices. In this article, we argue that a manager can navigate these tensions by understanding their firm, stra-tegic group, and industry identities and how these identi-ties interrelate. Through a qualitative case study of the U.S. recreational vehicle industry, we show that each level of identity influences different competitive actions, with firm identity connected to product offerings, indus-try identity related to managing downstream distribution, and strategic group identity related to firm boundary and acquisition strategies. Overall, strategic group identity is the most critical for managers as this level filters how they view competitors and provides the rules of competition. 


\section{1 | INTRODUCTION}

Organizations face a constant tension to maintain legitimacy by conforming to industry norms, but also to differentiate by creating a distinctive market presence and competitive position (Deephouse, 1999; Lieberman \& Asaba, 2006). From a strategic perspective, organizations establish their positions through actions to implement their corporate strategies, such as firm boundary decisions, entry modes, and management of interfirm relationships, and to implement their business strategies, such as product offerings. Rivals and industry stakeholders can observe these competitive actions, which are influenced both by economic drivers, such as supply and demand conditions and production technologies, and by cognitive drivers, such as how managers interpret and process information about their own organization, competitors, and the industry (Nadkarni \& Barr, 2008; Reger \& Huff, 1993). Whereas most work in strategy focuses on economic drivers, this paper examines cognitive drivers, specifically identity.

Organizational competitive actions are influenced by factors at multiple levels: the organization, the industry, and the strategic group. Work in organizational economics indicates each level influences strategy and performance (Porter, 1980; Short, Ketchen, Palmer, \& Hult, 2007). Research on strategic fit highlights coherence and combines multi-level factors to understand their influence on these actions such as firm boundary decisions, distribution channels, and product offerings (Fisher, 1997; Siggelkow, 2001; Teece, Rumelt, Dosi, \& Winter, 1994). This work tends to focus on economic drivers, such as capabilities, whereas related work on multi-level interpretive cognitive elements has been scant. This is an important omission as a manager's view of the environment affects organizational actions and strategies (Eggers \& Kaplan, 2013; Kiss \& Barr, 2015; Narayanan, Zane, \& Kemmerer, 2011; Porac, Thomas, \& Baden-Fuller, 1989). Our study addresses this gap by investigating the cognitive driver of identity, exploring the relationships between levels of identity, and connecting these multiple levels of identity to competitive actions.

Identity is defined as those characteristics that are central, enduring, and distinctive at organization (Albert \& Whetten, 1985), industry (Dhalla \& Oliver, 2013), and strategic group (Peteraf \& Shanley, 1997) levels, primarily observable to insiders participating at those levels. Identity as a construct allows scholars to explore how cognitive processes in an organization are related to competitive actions and competition at organization, industry, and strategic group levels (Ashforth, Rogers, \& Corley, 2011; Hsu \& Hannan, 2005; Porac, Thomas, \& Baden-Fuller, 2011). Although acknowledging that multiple levels exist, studies rarely combine these levels to understand how organizations draw concurrently on various levels of identity and how these relate to competitive actions, defined as observable behaviors "taken to select and implement the firm's strategy" (Ireland, Hitt, Camp, \& Sexton, 2001). ${ }^{1}$ Thus, our study asks: How do organizations negotiate tensions in strategic positioning at

\footnotetext{
${ }^{1}$ Ireland and colleagues use the term "strategic actions"; we chose the term "competitive actions" for these same activities to avoid confusion with "strategic groups."
} 
multiple levels of identity? And, knowing that identity and strategy interact, how does each level of identity relate to the competitive actions that organizations implement?

Since the connections between levels of identity and competitive actions are understudied, we approached our analysis inductively through a qualitative study of the recreational vehicle (RV) industry, which includes manufacturers of motorhomes and towable camping trailers. This industry is technologically mature, has distinct boundaries, and consists of seven relatively homogenous organizations. Through a longitudinal study, we investigated how firms draw on nested levels of identity to shape conformity and differentiation in their competitive actions. Our findings emerged in two key stages. First, we found that the levels of identity are nested, with organizations attending to all three levels, conforming to pressures of industry identity while drawing on organizational identity and strategic group identity for differentiation. Second, we found these levels of identity are associated with actions taken by firms in patterned ways. We find that organizational identity relates to business-level decisions on product offerings; industry identity relates to the corporate-level strategies involved in managing downstream relationships; and strategic group identity relates to corporate-level strategies connected to firm boundaries and entry modes. Moreover, we uncover the key role played by strategic group identity in filtering the industry identity to align with group and organizational identities, and thus allow for both conformity and differentiation. From these findings, we develop a conceptual model that links nested identities to competitive actions as filtered through strategic group identity, and suggest that a multi-level analysis of identity is necessary to understand how this cognitive construct relates to corporate and business strategies.

This study provides several contributions toward a richer understanding of the role of cognition in strategy. First, by linking these levels of identity and strategy, we provide insight into cognitive aspects of organizations managing tension between conformity and differentiation. Whereas organizational identity relates to specific product-level actions (the "what"), industry identity outlines the players, norms, and boundaries of the competitive space (the "who"), and strategic group identity addresses the approach to competition (the "how"). The combination of these nested identities influences how firms interpret their overall competitive landscape and thus informs their actions to implement business- and corporate-level strategies, allowing them to both conform and differentiate. Second, our findings highlight the role of strategic group identity as a reference point for both interpreting and formulating competitive positioning. This level is key to managing the conformity-differentiation balance by allowing organizations to distinguish themselves without facing legitimacy threats. Strategic group identity provides a filter through which organizations can enact industry identity and a context for interpreting organizational identity. Finally, our model expands our understanding of how identity can drive strategy as it connects levels of identity to specific competitive actions, indicating cognitive aspects of how managers take actions aligned with these identities to compete while remaining legitimate.

This paper proceeds as follows. First, we summarize the literature on organization, industry, and group-level identities, and how they relate to competitive actions. Next, we recount our inductive investigation in the RV industry. We then present our findings and develop a model linking identities and competitive actions. We finish by presenting contributions, developing propositions, and discussing limitations and extensions.

\section{2 | MULTIPLE LEVELS OF IDENTITY AND STRATEGY}

Research has explored identity as both a fairly stable cognitive frame, or set of "characteristics" (e.g., Albert \& Whetten, 1985), and as a negotiated process (e.g., Gioia, Price, Hamilton, \& Thomas, 2010). We focus on the characteristic view of identity for two reasons. First, the process view of identity explores internal dynamics of organizations and focuses on individuals, whereas we 
examine firms as social actors within their broader environments. Second, our data show no evidence of identity renegotiation, as identities are stable during our investigation. We also focus on how organizational, strategic group, and industry levels of identity interrelate and affect behavior, taking a normative, rather than a process, perspective.

\subsection{Organizational identity}

The characteristics of an organization that are central, enduring, and distinctive constitute organizational identity (Albert \& Whetten, 1985) and it both constrains and aligns behavior, enabling actors to act through their shared understandings of "who the firm is" (Ashforth et al., 2011). Organizational identity informs managers' strategic choices, as they filter the competitive context through their own beliefs about the organization, and so align actions with identity. Organizational identity can be a source of competitive advantage, as managers draw on these unique characteristics to differentiate (Fiol, 2001). Managers act and react to competitors' actions based on how they understand their organization's identity, both internally and with respect to others (Porac et al., 1989). Identity claims can motivate organizations to compete more heavily in some markets than others because they perceive a good fit, even these markets are less profitable (Livengood \& Reger, 2010). Likewise, this level of identity guides decisions around vertical and horizontal boundaries (Santos \& Eisenhardt, 2005).

Some work notes organizations can have multiple identities, which can cause tensions (Fiol, Pratt, \& O'Connor, 2009; Moss, Short, Payne, \& Lumpkin, 2011). Individuals often feel tensions between their organization's multiple identities, to which they respond by identifying with one identity over the others, often the one closest to their personal identity (Foreman \& Whetten, 2002; Glynn, 2000). Tensions between identities in an organization can lead to "intractable conflicts" (Fiol et al., 2009), as some identify more closely with different identities in the organization, which impedes action (Ashforth \& Reingen, 2014; Glynn, 2000). Although this work demonstrates the complexity of multiple identities at the same level, we still lack an understanding of how levels of identity interrelate and how this affects actions.

\subsection{Industry identity}

Organizations are members of industries, and these industries have definitions of who they are collectively. Dhalla and Oliver (2013) define an industry identity as "a collective understanding or shared set of beliefs widely held by members of an industry about what constitutes the central, enduring, and distinctive characteristics of the industry as a whole and its members" (p. 1804). Aligning with this identity involves conforming to the industry's norms, where non-compliance can lead to illegitimacy and punishing behavior by members attempting to maintain the identity (Ashforth et al., 2011; Hsu \& Hannan, 2005; Porac et al., 1989). Identity thus sets behavioral boundaries, delineating which actions are acceptable (Porac et al., 1989).

Industry identity can also influence organizational performance. Shared understandings among industry members reduce coordination and transaction costs, adding predictability and avoiding continual adaptation. Organizations with a strong industry identity are unlikely to change, even in the face of strong external demands (Dhalla \& Oliver, 2013). Industry identity relates to a set of shared mental models that motivate imitation between firms that moderates competitive actions and assists in the industry's long-term survival (Porac et al., 1989). 


\subsection{Strategic group identity}

Strategic groups are collections of organizations that pursue similar strategies within an industry and see themselves more closely in competition with members of their group than others (Porter, 1980). As organizations tend to compete more closely against a subset of organizations, the strategic group is often seen as a bridge for analyzing connections between organization and industry levels (Porac et al., 2011; Reger \& Huff, 1993).

Economists researching strategic groups suggest organizations compete most vigorously with close competitors and argue organizations stake out positions, such as differentiators or cost leaders (Chen \& Miller, 2012; Porter, 1980). These scholars posit managers primarily base decisions on availability and type of resources, and fit with each approach (Fisher, 1997; Porter, 1991; Teece et al., 1994). Complementary to this view, the cognitive perspective focuses on underlying thought processes that guide managers to select the positioning, allocations, or actions that form strategy (Narayanan et al., 2011; Porac et al., 1989). As with industry identity, a group of organizations' perceptions of who they are constitute its strategic group identity and reinforce managers' decisions (Reger \& Huff, 1993). Note that economic strategic groups may not be the same as cognitive strategic groups, as the latter are more subjectively determined.

Peteraf and Shanley (1997) defined strategic group identity as "a set of mutual understandings... regarding the central, enduring, and distinctive characteristics of the group" (166). As with other identities, strategic group identity frames managers' understandings of their group, leading them to consider a limited range of "appropriate" strategic options (Narayanan et al., 2011). This bounded cognition with its shared mental models results in conformity and predictable actions. But, organizations within the group still must be distinctive in the market (Chen \& Miller, 2012; Livengood \& Reger, 2010). Thus, this level of identity is crucial to organizations balancing conformity and differentiation.

\section{4 | Tensions between multiple levels of identities}

We build on prior research by investigating the tensions between organizational, industry, and strategic group identities and how these influence competitive actions. Industry and strategic group identities create pressure for conformity: organizations that do not fit may be ostracized or seen as illegitimate. Identity, however, is not just about belonging but also about what is distinctive. An organization's identity cannot be distinctive if it fully conforms to strategic group or industry identities, just as it cannot develop competitive advantage without unique actions or resources (Barney, 1991; Fiol, 2001). A tension thus arises between an organization's needs to conform and to create an identity distinct from competitors (Deephouse, 1999; Navis \& Glynn, 2010). This tension manifests in the organization's competitive actions, which reflect how they concurrently draw on all identity levels.

\section{3 | RESEARCH CONTEXT AND METHODS}

Since identity and competitive actions relationships are understudied, we took a qualitative, inductive approach (Eisenhardt \& Graebner, 2007). Using archival, interview, and observational data from the U.S. recreational vehicle (RV) industry from 2008 to 2016, we investigate identity and strategy links at the organization, industry, and strategic group level. We chose this industry due to its maturity, tractable size, and the commonality of economic drivers, which allow us to focus on identity. We began by gathering data about firms' observable competitive actions, such as product offerings, 
firm boundaries, and dealer relationships. We found differences in firms' competitive actions that could not be explained with economic drivers, which led us to investigate identity. Further, the identities of two distinct strategic groups emerged from our data, Assemblers and Crafters. We found patterns of competitive actions aligned with organizational, strategic group, and industry claims and it became clear that although firms may engage in objectively similar actions, such as supporting dealer relationships, the identities driving those decisions could be quite different and that these identities were nested, influencing the boundaries of behavior. Please see Table 1 for a summary of significant competitive actions and identity drivers in the RV industry.

\section{1 | Research context: The U.S. Recreational Vehicle (RV) industry}

The U.S. RV industry was established in the mid-twentieth century, is relatively small, and is technologically mature. Industry sales are around $\$ 11$ billion, with roughly 370,000 units produced annually ( $\sim 87 \%$ towable trailers, the rest motorhomes) and about $8.5 \%$ of U.S. households owning an RV. The industry's trade association, the Recreation Vehicle Industry Association (RVIA) organizes the industry's annual tradeshow and shared marketing campaign. Seven firms (Fleetwood RV, Forest River, Jayco, Newmar, Thor Industries, Tiffin, and Winnebago Industries) constitute the majority of the industry, covering over $85 \%$ of the market, with no dominant market leader. Product segments include bus-like Type A motorhomes, van-like Type B motorhomes, Type C motorhomes based on truck chassis, fifth-wheel trailers, and traditional towable trailers. Prices range from $\$ 10,000$ for a simple trailer to over $\$ 500,000$ for a residential, diesel Type A. The production process involves assembling 3,000 or more components including the chassis, electrical systems, appliances, plumbing, cabinetry, and furniture. Organizations use the same suppliers, some of which are much larger (e.g., Ford, Freightliner, and Sony). Independent dealers carry models from multiple manufacturers, sell new and used units, and have discretion in pricing. See Table S1 in the Appendix S1 for more details.

\section{2 | Methods}

This study was designed to identify connections between different levels of identity within an industry and the competitive actions taken by firms within that industry. This small, mature industry is ideal for several reasons: firms' products are similar, so distinctions in competitive actions and identity are not tied to differentiation of products; firms share the same suppliers, distributors, and customers, so identity and competitive actions will not be driven by access to resources or markets; the technology is mature, so innovation is generally incremental and quickly diffused, creating little differentiation. Thus, differences in identity and strategy can more readily be observed without confusion with other aspects of the industry.

We used qualitative methods to capture the nuances needed to understand identity at multiple levels. Our embedded, inductive case study of all seven firms within the industry is intended to develop midrange theory. We followed a pattern-matching logic (Gibbert, Ruigrok, \& Wicki, 2008; Yin, 2003), tracing key activities and comparing these to understand how they differed, focusing on identities and competitive actions. We supplemented the qualitative identity data with quantitative data on competitive actions to track the prevalence of particular actions in relationship to specific identity claims. Understanding identity required obtaining perspectives from those inside the industry and each firm as it is interpreted by those familiar with "who the firm is" (Albert, Ashforth, \& Dutton, 2000); whereas competitive actions are both observable and objective, and thus could be measured through descriptive quantifiable data (Ireland et al., 2001). This approach is consistent 


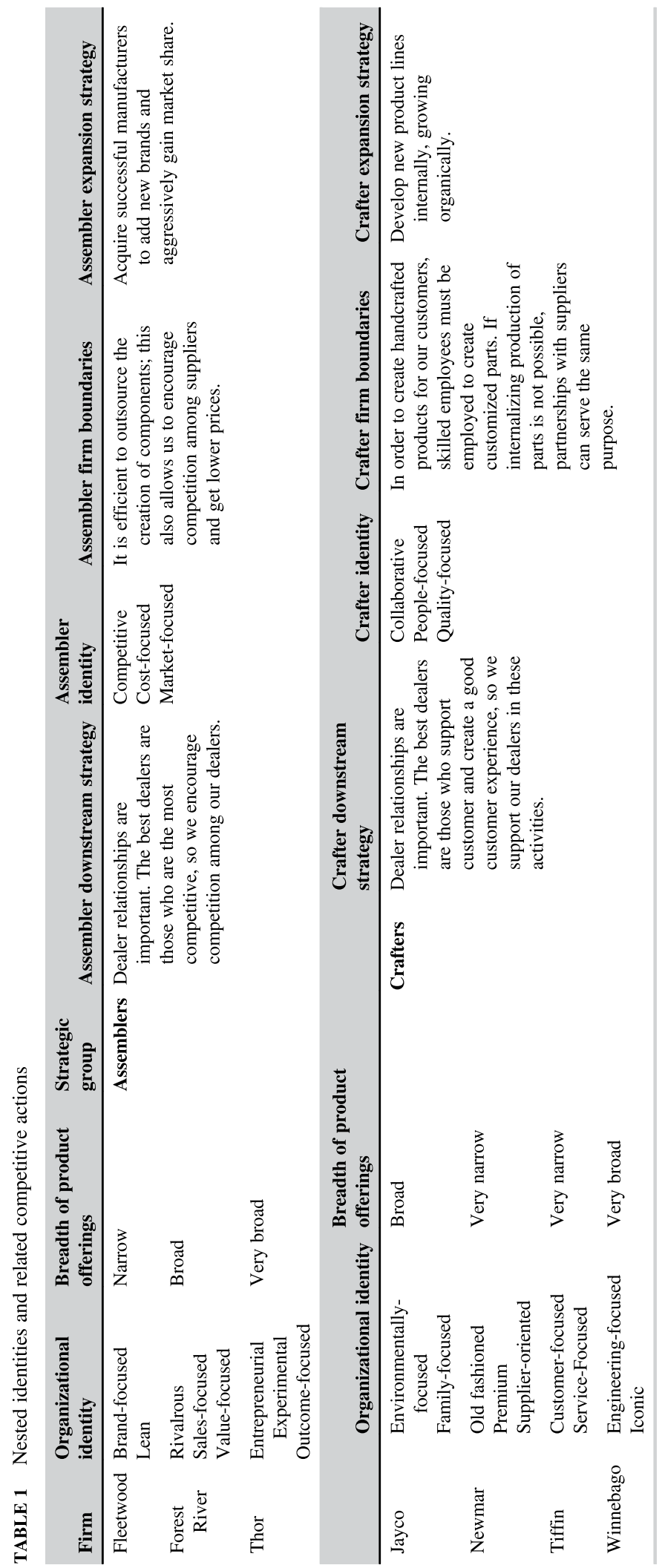


with our research goals and assumptions made in similar studies (e.g., Patvardhan, Gioia, \& Hamilton, 2015).

\section{3 | Data}

Our data were gathered from archival, interview, and observation data over a seven-year period (see Appendix Table S2 for a full list of sources). To begin to understand the industry, we focused on observable differences in firms, as indicated by their competitive actions. As these are objective and observable to the market, we could gather and analyze information from industry trade publications, $R V$ Business and RV Pro, related to product offerings, acquisitions, supplier activity, and dealer meetings. We tabulated these competitive actions by firm and supplemented it with data from websites, videos, brochures, and SEC filings. For product data, we consulted the annual Trailer Life Buyer's Guide.

To more deeply understand the industry, we attended the annual trade show from 2008 through 2013. The RVIA runs this show for suppliers, dealers, and manufacturers, not the public. We attended plenary sessions, observed displays, and interviewed representatives from dealers, suppliers, and manufacturers. We also attended several public RV shows and visited five manufacturers' facilities, taking private and public tours to observe their processes and interview personnel. This was especially helpful to understand firm boundary decisions and dealer and supplier relationships, which are less publicized, but well understood by industry insiders. Many interviews were conducted during factory tours, so we were not able to record them and instead took detailed notes. Plant interviews included sales staff, dedicated tour guides, and managers to ensure that no single point of view dominated our understanding (Gibbert et al., 2008; Miles \& Huberman, 1994).

Through tabulation of these data, initial observations, and interviews, we observed differences in firms' competitive actions, which was surprising as firms operate under similar economic drivers. They had differences in strategic behavior both at the corporate level (e.g., choice of firm boundaries, growth by acquisition or organically, interfirm relationships) and at the business level (e.g., breadth of product offerings, employment practices, use of manufacturing space). To investigate these differences, we continued our interviews, revising questions to understand insider perspectives on these differences. These interviews pointed us toward identity, as the firms displayed distinctive personalities and attributes. For example, one respondent, a grandson of a firm founder, said that if you grew up near Elkhart, you knew by high school who was going to work for which RV firm because certain people just fit with certain firms, indicating the surrounding communities had a sense of the firms' identities and who "belonged" with a given firm. Thus, we believed that identity could provide an explanation for these differences and then explored this construct in more depth empirically. As identities are held within and between people, we interviewed firm employees, RVIA representatives, dealers, and suppliers.

To more fully explore organizational and industry identities, we also analyzed trade publications. We focused on interviews of firm executives as well as articles on industry-level issues such as the economic downturn or regulatory changes, believing these would be most likely to reveal characteristics of organizational and industry identities. We collected data from RVIA and firms' websites, videos, and promotional materials. These data were coded to uncover broader themes and identity claims.

This round of investigation highlighted a curious phenomenon: there appeared to be two distinct groups in the industry. One group seemed more corporate, emphasizing sales volumes, competition, value propositions, and efficient processes, meeting visitors with guard shacks and locked gates. The second group seemed more familial, emphasizing customers, employees, community, and the 
craftsmanship of their products. These firms greeted visitors with a welcome center, complete with firm and founder histories, information on owners' groups, firm mascots, and branded merchandise. Further interviewees, including several manufacturer executives, a key chassis supplier, and a major dealer who worked with all the firms, confirmed that the industry was divided into two groups. As the incoming new president of the RVIA also confirmed (RVB Jan/Feb 2016):

You've got home-grown family businesses. You've got the growing public companies that are becoming more and more dynamic and expanding through professional processes and best practices. You've got an M\&A culture and very large, fast growing, visionary brands.

\section{4 | Analysis}

Our approach to analysis was iterative, moving between the data and theory to inform our data collection and analysis. We identified broad categories of competitive actions based on their repeated mentions in the data sources. The most significant actions that emerged were product offerings (the breadth of offerings across and number of models within each type), downstream strategies (the number of dealers and how firms managed them), firm boundaries (vertical integration choices and supplier relationships), and modes of expansion (acquisition vs. organic growth). Data on firm product offerings are summarized in Table 2, and data on dealer relationships, expansion strategies, and vertical integration are summarized in Table 3. Initial examination of the actions alone created no clear patterns-firms behaved differently, as we had seen earlier, but the patterns of difference were inexplicable on their own, with some firms appearing similar across some actions but differing importantly on others for no clear reason.

Our qualitative data suggested identity as a promising explanation to the seemingly disconnected patterns we were seeing in firms' competitive actions. Drawing on interview notes as background, we coded articles from trade journals and video transcripts, looking for identity characteristics claimed for each firm by its members, as well as characteristics claimed for the industry by both firm members and the industry association. We accepted as identity characteristics those statements where industry members expressed a characteristic as representative of a firm (organizational identity) or the industry (industry identity), and emergently developed descriptive codes based on these data. Separately, the authors then coded the qualitative data for the characteristics speakers were claiming as part of an identity (e.g., "handcrafted," "traditional," "aggressive"), writing notes on codes and creating working memos on identity profiles rising from the data. We examined each other's codes for comparability, simplified the codes where applicable, and discussed differences, leading to a shared coding scheme. We independently coded the data a second time and found significant agreement. We then consolidated codes that shared similar characteristics into emergent themes. See Table S3 in the Appendix S1 for a list of identity codes, associated themes, and exemplary quotes.

We revisited the qualitative data with the emergent themes to examine the identity claims attributed to individual firms and found three types of claims. First, there were claims made by firms to create a unique identity claim set (see Table 4). Second, there were claims shared by all or most firms. Because these claims were ubiquitous in the industry, we determined they were part of the industry identity. Both the claims directly coded as industry identity and those shared by all firms are listed in Table 5. Finally, we found that some claims were shared by groups of firms but not the industry as a whole, and that these shared claims separated the industry into two distinct groups. 
TABLE 2 Data on business-level competitive actions: Product offerings by firm

\begin{tabular}{|c|c|c|c|c|c|c|c|c|c|c|}
\hline \multirow[b]{2}{*}{ Company } & \multirow[b]{2}{*}{ \# Brands } & \multirow[b]{2}{*}{$\begin{array}{l}\text { Total } \\
\# \\
\text { models }\end{array}$} & \multicolumn{8}{|c|}{ Number of models offered by product type (2015) } \\
\hline & & & $\begin{array}{l}\text { Mot. } \\
\text { (A) }\end{array}$ & $\begin{array}{l}\text { Mot. } \\
\text { (B) }\end{array}$ & $\begin{array}{l}\text { Mot. } \\
\text { (C) }\end{array}$ & $\begin{array}{l}\text { Fifth } \\
\text { wheel }\end{array}$ & $\begin{array}{l}\text { Travel } \\
\text { trailer }\end{array}$ & $\begin{array}{l}\text { Pop- } \\
\text { up }\end{array}$ & $\begin{array}{l}\text { Mfg. } \\
\text { housing/ } \\
\text { Park } \\
\text { models }\end{array}$ & Bus / Other \\
\hline Fleetwood & $\begin{array}{l}4 \text { (Fleetwood, American } \\
\text { Coach, Monaco, } \\
\text { Holiday Rambler) }\end{array}$ & 24 & $19^{\mathrm{a}}$ & 0 & 5 & 0 & 0 & 0 & No & $\begin{array}{l}\text { Yes (sister div; also } \\
\text { emergency } \\
\text { vehicles) }\end{array}$ \\
\hline $\begin{array}{l}\text { Forest } \\
\text { River }\end{array}$ & $\begin{array}{l}6 \text { (Forest River, } \\
\text { Coachmen, Prime Time, } \\
\text { Palomino, Shasta, } \\
\text { Dynamax) }\end{array}$ & 184 & 7 & 0 & 16 & 56 & 96 & 9 & Yes & $\begin{array}{l}\text { Yes (also pontoon } \\
\text { boats) }\end{array}$ \\
\hline Jayco & $\begin{array}{l}4 \text { (Jayco, Entegra, } \\
\text { Starcraft, Highland } \\
\text { Ridge) }\end{array}$ & 38 & $5^{\mathrm{a}}$ & 0 & 4 & 10 & 17 & 2 & Yes & No \\
\hline Newmar & 1 (Newmar) & 10 & $10^{\mathrm{a}}$ & 0 & 0 & 0 & 0 & 0 & No & No \\
\hline Thor & $\begin{array}{l}11 \text { (Thor Motorcoach, } \\
\text { Airstream, Keystone, } \\
\text { Dutchmen, Crossroads, } \\
\text { Cruiser, DRV, KZ, } \\
\text { Bison, Heartland, } \\
\text { Livin'Lite) }\end{array}$ & 184 & 11 & 3 & 9 & 63 & 92 & 6 & Yes & $\begin{array}{l}\text { Yes (got out in 2013; } \\
\text { bought Aluminum } \\
\text { firm in 2015) }\end{array}$ \\
\hline Tiffin & 1 (Tiffin) & 6 & $6^{\mathrm{a}}$ & 0 & 0 & 0 & 0 & 0 & No & No \\
\hline Winnebago & $\begin{array}{l}3 \text { (Winnebago, Itasca, } \\
\text { Sunnybrook but } \\
\text { dropped Itasca in Nov } \\
\text { 2015) }\end{array}$ & 37 & 18 & 2 & 8 & 3 & 6 & 0 & No & $\begin{array}{l}\text { No (got out of bus in } \\
\text { 2015) }\end{array}$ \\
\hline
\end{tabular}

${ }^{\text {a }}$ Offers Type A over $\$ 500 \mathrm{~K}$.

These identity groups aligned with the strategic groups identified by our early investigation and in interviews with industry members. We list these strategic group identity claims in Table 6.

After completing coding, we developed brief identity memos for each firm, the industry, and each strategic group. We reviewed the notes from both trade show and site visit interviews and found the identities developed from the coding were in close alignment to the way firm members described them in interviews. This corroboration of what was publicly available with what was relatively privately said affirmed for us that we had correctly identified the claims made at each level. In follow-up interviews, we asked some field members about the strategic groups we had identified and they confirmed both the existence of and identity of these groups and agreed with our determination of members.

\section{4 | FINDINGS}

In this section, we discuss our findings, focusing on two points: how the levels of identity interact and how they connect to competitive actions. We first describe how organizations draw on each of three levels of identity and how those levels interrelate (see Figure S1 in the Appendix S1 for an overview). Note that organizational identity is not expressed simply as "who we are" but also "how we do what we do" (Clegg, Rhodes, \& Kornberger, 2007; Navis \& Glynn, 2010), such as when a Fleetwood manager claims they are lean. This contrasts with competitive actions that are observable and objective firm behaviors, such as when Thor purchases a towable firm. 
TABLE 3 Data on corporate-level competitive actions: Dealer relationships, firm boundaries, and expansion modes

\begin{tabular}{|c|c|c|c|c|c|c|}
\hline \multirow[b]{2}{*}{ Company } & \multicolumn{2}{|c|}{$\begin{array}{l}\text { RVDA Quality } \\
\text { Circle Dealer } \\
\text { Satisfaction } \\
\text { Award } \\
(\mathbf{2 0 0 8 - 2 0 1 5 )}\end{array}$} & \multirow[b]{2}{*}{ \# of Dealers } & \multirow{2}{*}{$\begin{array}{l}\text { Vertical integration } \\
\text { \% Inputs manufactured } \\
\text { in-house }\end{array}$} & \multicolumn{2}{|l|}{ Expansion by acquisition } \\
\hline & $\begin{array}{l}\text { Years } \\
\text { rcv'd } \\
\text { (Mot.) }\end{array}$ & $\begin{array}{l}\text { Years } \\
\text { rcv'd } \\
\text { (Tow.) }\end{array}$ & & & $\begin{array}{l}\text { Mergers \& acquisitions } \\
\text { (since 2008) }\end{array}$ & $\begin{array}{l}\text { Type of } \\
\text { company } \\
\text { acquired }\end{array}$ \\
\hline Fleetwood & 0 & N/A & 100 estm. & $\begin{array}{l}(\sim 35 \%) \text { Fiberglass, } \\
\text { Woodwork }\end{array}$ & $\begin{array}{l}\text { Purchased by Allied } \\
\text { Specialty Vehicles (ASV); } \\
\text { Purchased } 2 \text { brands since } \\
2010\end{array}$ & RV \\
\hline $\begin{array}{l}\text { Forest } \\
\text { River }\end{array}$ & 4 & 3 & 2,000 estm. & $(\sim 5 \%)$ Some woodwork & $\begin{array}{l}\text { Purchased } 10 \text { companies } \\
\quad \text { since } 1996 ; 2 \text { since } 2008\end{array}$ & $\begin{array}{l}\text { RV, Bus, } \\
\text { Materials, } \\
\text { Financial } \\
\text { services }\end{array}$ \\
\hline Jayco & 8 & 8 & $\begin{array}{l}190(87 \\
\quad \text { exclusive })\end{array}$ & $\begin{array}{l}(\sim 70 \%) \text { Aluminum, } \\
\text { Fiberglass, Plastic, Soft } \\
\text { goods, Steel, Woodwork }\end{array}$ & $\begin{array}{l}\text { Purchased } 2 \text { companies in } \\
2008 \& 2014\end{array}$ & RV \\
\hline Newmar & 3 & N/A & 54 & $\begin{array}{l}(\sim 50 \%) \text { Aluminum, Soft } \\
\text { goods, Woodwork }\end{array}$ & 0 & None \\
\hline Thor & 3 & 8 & 2,100 & $(\sim 1 \%)$ Some aluminum & $\begin{array}{l}\text { Purchased } 11 \text { companies } \\
\quad \text { since } 2008\end{array}$ & $\begin{array}{l}\text { RV, Bus, } \\
\text { Materials }\end{array}$ \\
\hline Tiffin & 8 & N/A & 85 & $\begin{array}{l}(\sim 9 \%) \text { Chassis, Aluminum, } \\
\text { Fiberglass, Plastic, Soft } \\
\text { goods, Steel, Woodwork }\end{array}$ & 0 & None \\
\hline Winnebago & 8 & 0 & $\begin{array}{l}293 \text { (mot) } 137 \\
\text { (tow) }\end{array}$ & $(\sim 60 \%)$ & Purchased 1 firm & RV \\
\hline
\end{tabular}

\footnotetext{
${ }^{a}$ Vertical Integration includes percentage of the following processes: Chassis; Aluminum parts (doors, windows, etc.); Fiberglass parts (front and end caps, showers, sidewalls); Plastic parts (holding tanks, etc.); Soft goods (furniture, curtains, etc.); Steel parts; Woodwork (cabinets, etc.)
}

\subsection{Levels of identities and their relationships}

\subsection{1 | Organizational identities}

Unsurprisingly given past research, each organization in our study developed and maintained a unique, enduring set of identity characteristics (Albert \& Whetten, 1985). Each firm makes claims unique to their firm in an attempt to differentiate from peers.

Fleetwood's identity claims focus on being brand-focused and lean, exemplified by the firm's approach to production and branding. Fleetwood was previously larger, but after its 2008 bankruptcy and purchase by Allied Specialty Vehicles (now REV Group), their product lines have been downsized. Fleetwood emphasizes their firm's history and classic models, but most prevalent in their identity claims are statements of efficiency and lean production.

Forest River defines itself as rivalrous, sales-focused, and value-focused. They emphasize competition, as one salesman stated, "you won't find anyone in the building who can match this price." This "Wild West" style is reflected in their production plants. During our visit, the plant floor was cluttered and disorganized, workers listened to fast-paced rock music, were dressed in ripped jeans, and rapidly moved rigs along, as they are paid on piecework.

Jayco's identity claims center on being environmentally- and family-focused. Visitors are greeted with a welcome center, emphasizing they are family-owned and managed, while video tours assert employees are like family. The intergenerational involvement and care of the founders is appreciated by dealers, with one saying, "We're here to stay and we think they're here to stay and 
TABLE 4 Themes and claims associated with organizational identities

\begin{tabular}{|c|c|c|}
\hline Firm & Associated themes & Identity claims \\
\hline Fleetwood & $\begin{array}{l}\text { Aggressive } \\
\text { Brand-oriented } \\
\text { Dealer-oriented } \\
\text { Efficient } \\
\text { Innovative } \\
\text { Sales-oriented } \\
\text { Traditional } \\
\text { Wholesome }\end{array}$ & $\begin{array}{l}\text { Brand-focused } \\
\text { Lean }\end{array}$ \\
\hline Forest River & $\begin{array}{l}\text { Aggressive } \\
\text { Dealer-oriented } \\
\text { Sales-oriented } \\
\text { Traditional } \\
\text { Value-oriented }\end{array}$ & $\begin{array}{l}\text { Rivalrous } \\
\text { Sales-focused } \\
\text { Value-focused }\end{array}$ \\
\hline Jayco & $\begin{array}{l}\text { Dealer-oriented } \\
\text { Employee-oriented } \\
\text { Family-oriented } \\
\text { Handcrafted } \\
\text { Innovative } \\
\text { Reliable } \\
\text { Sustainable }\end{array}$ & $\begin{array}{l}\text { Environmentally-focused } \\
\text { Family-focused }\end{array}$ \\
\hline Newmar & $\begin{array}{l}\text { Caring } \\
\text { Dealer-oriented } \\
\text { Handcrafted } \\
\text { Innovative } \\
\text { Luxurious } \\
\text { Reliable } \\
\text { Service-oriented } \\
\text { Supplier-oriented } \\
\text { Talented } \\
\text { Traditional }\end{array}$ & $\begin{array}{l}\text { Old fashioned } \\
\text { Premium } \\
\text { Supplier-focused }\end{array}$ \\
\hline Thor & $\begin{array}{l}\text { Aggressive } \\
\text { Dealer-oriented } \\
\text { Engineered } \\
\text { Innovative } \\
\text { Reliable } \\
\text { Sales-oriented } \\
\text { Service-oriented } \\
\text { Traditional } \\
\text { Value-oriented }\end{array}$ & $\begin{array}{l}\text { Entrepreneurial } \\
\text { Experimental } \\
\text { Outcome-focused }\end{array}$ \\
\hline Tiffin & $\begin{array}{l}\text { Caring } \\
\text { Design-oriented } \\
\text { Employee-oriented } \\
\text { Family-oriented } \\
\text { Handcrafted } \\
\text { Reliable } \\
\text { Service-oriented } \\
\text { Wholesome }\end{array}$ & $\begin{array}{l}\text { Customer-focused } \\
\text { Service-focused }\end{array}$ \\
\hline Winnebago & $\begin{array}{l}\text { Brand-oriented } \\
\text { Caring } \\
\text { Design-oriented } \\
\text { Engineered } \\
\text { Handcrafted } \\
\text { Innovative } \\
\text { Reliable } \\
\text { Service oriented } \\
\text { Talented } \\
\text { Traditional } \\
\text { Unique }\end{array}$ & $\begin{array}{l}\text { Engineering-focused } \\
\text { Iconic }\end{array}$ \\
\hline
\end{tabular}


TABLE 5 Themes and claims associated with industry identity

\begin{tabular}{lll} 
& Associated themes & Identity claim \\
\hline Industry & Dealer-oriented & Relationship-focused \\
& Service-oriented & \\
& Traditional & \\
& Wholesome & \\
\hline
\end{tabular}

that's the kind of company I like to be with - a family-owned company who cares" (RVPro, 2015). Jayco also tries to differentiate by highlighting sustainable practices.

Newmar focuses their identity claims on being old-fashioned, premium, and supplier-focused. Much of their website, videos, and marketing materials emphasize the quality and handcrafted work put into their products. Our tour guide told us that they do things the "old-fashioned way," building with stick-and-tin walls, in a factory that is spotless, with one employee stating, "they have rules here and I like it that way." The company leverages employees' skills in developing custom, highend products with luxurious interiors. Newmar co-develops exclusive products with suppliers and hosts an annual supplier appreciation dinner.

Thor's identity claims focus on being entrepreneurial, experimental, and outcome-focused. They emphasize melding competition and innovation, encouraging divisions to compete in developing innovative designs, obtaining dealers, and gaining sales. Thor's experimentation is exemplified in their emphasis on quickly creating and launching new products and cutting underperformers. Thor's focus on outcomes includes cost efficiencies, exemplified by automated processes, and competition, represented by wire fences separating each division's buildings.

Tiffin's identity claims center on being customer- and service-focused. Tiffin is one of two major RV firms based outside Indiana, and advertises that people in Red Bay, Alabama are "just different." Tiffin offers the most extreme example of customer care in the industry: the founder attends RV shows, gives tours, and answers customers' calls. Many managers in the firm are his descendants and they repeatedly laud the skill of their employees, drawing together their claims of quality, location, and family to support the highest quality customer service. Tiffin can also procure parts for every rig they have produced to provide top-notch service support.

TABLE 6 Themes and claims associated with strategic group identities

\begin{tabular}{lll} 
Groups & Associated themes & Identity claims \\
\hline Assemblers & & Competitive \\
Fleetwood & Aggressive & Cost-focused \\
Forest River & Brand-oriented & Market-focused \\
Thor & Efficient & \\
& Innovative & Collaborative \\
& Sales-oriented & People-focused \\
Crafters & Value-oriented & Quality-focused \\
Jayco & & \\
Newmar & Caring & \\
Tiffin & Design-oriented & \\
Winnebago & Employee-oriented & \\
& Engineered & \\
& Family-oriented & \\
& Handcrafted & Luxurious \\
& Reliable &
\end{tabular}


Winnebago's identity claims focus on being engineering-focused and iconic. Their promotional materials emphasize their iconic brand of high-quality products, carefully developed by engineers and produced by skilled employees. Winnebago highlights their engineering expertise and durability of its designs, even testing new models by dropping from a crane. Winnebago offers truly innovative products, having the staff to redesign their vehicles and utilize new technologies, such as a hybrid chassis. Winnebago's facilities reflect their identity with well-organized production processes and a visitor's center that showcases their history.

Although these firms create similar products using a common production technology and work with the same dealers and suppliers, it is clear that they have distinct identities, played out not only in how they talk about themselves, but also in the ways in which they do their work.

\subsubsection{Industry identity}

Our analyses show that the RV industry identity centers around relationships. Underlying this overarching identity claim is an emphasis on collegiality, a positive attitude, and traditional, "Midwestern values." As the COO of Thor said in a 2012 interview

[L]et's not forget that we have the privilege of working in the RV industry, and it really is a privilege. In what other sector do the manufacturers, dealers, suppliers, infrastructure providers, campground owners bond together to provide the consumer the best vacation experience and value for the dollar?

Industry members expect one another to build strong relationships with suppliers, customers, and especially dealers. As articulated by a key supplier: "We fish, eat, drink together... we know each other's family." This is corroborated by Doug Gaddaert, industry spokesman and Forest River executive, who commented: "While everyone's out to kick each other's butts in the marketplace, they're also good at selflessly coming together for the common good" (RVB, 2015). Likewise, an RV Business writer noted: "All (inductees to the RV Hall of Fame) cited the unique camaraderie among peers that is at the core of the RV industry, along with the satisfaction and reward of 'selling fun' to the American public."

Positivity and collegiality are touted as the bedrock of the industry at the RVIA trade show that begins with the Outlook Breakfast, featuring home-style food, oldies bands, and the RVIA president's forecast. Even in 2009, when the credit collapse pummeled the industry, the program included a rework of the tune "Age of Aquarius" ("We're done living in an age so precarious/ Times so nefarious/ Can't bury us/ Be there with us") with speeches calling for everyone to "celebrate the optimism." Industry players all come together at this show to highlight new models, book orders, and strengthen relationships.

\subsection{3 | Strategic group identities}

The RV industry has two strategic groups that emerged from our analysis of organizations' identities, which we labeled "Assemblers" and "Crafters." Firms in the Assemblers group include Fleetwood, Forest River, and Thor. These firms all claim identities that include a competitive, cost-focused, and market-focused business approach. Assemblers tend to emphasize the value proposition of their products - "bang for the buck" - supported through streamlined processes and assembling pre-made components. They are competitive, both internally and externally, encouraging competition among dealers and suppliers, as well as among their divisions. Fleetwood President Jim Jacobs exemplifies this: "I'm aggressive with price points and content. We are here to win... We like 
market share and we like building brands out. We like being the dominant player in every sector" (RV Pro, 2016).

The competitive nature of this group is evident in the firms' approaches to organizational structure and physical space. Forest River and Thor encourage divisions to compete, allowing them to have similar products and fight for dealers. As Thor's Bob Martin said in a 2014 interview, "[O]ur companies are highly decentralized, and whatever my corporate team does can't interfere with what the companies do" (RVB, 2014). Assemblers offer factory tours, but prohibit cameras and strictly control visitor access.

The Crafter group includes Jayco, Newmar, Tiffin, and Winnebago. In contrast to Assemblers, Crafter organizations emphasize identity claims centered on collaboration, focusing on people and quality. They prefer detail-oriented, hand-crafted manufacturing processes, stressing quality control and customer service. They promote their products as durable, high-quality, and customized, while also emphasizing a warm, familial atmosphere. For instance, Jayco emphasizes their caring and reliability as a family-owned firm:

No matter how big we get, we're going to continue to build high quality products, just like my grandpa did many years ago. ... "Generations of family fun" is more than just a tag line to us, it is a brand promise. We plan to be around for generations to come. (Jayco company video, 2014)

These claims are apparent in their physical plants. All the Crafters we visited had organized, clean workspaces with neatly dressed employees who worked efficiently and calmly with many quality checks. These firms offered regular tours, encouraging photos and interactions with workers. Rather than guard shacks, they had visitor centers, where one could tour models, chat with employees, and buy branded merchandise, like mugs and toys.

\subsection{4 | Summary: Interrelated, nested levels of identity}

In sum, we see organizations draw on three levels of identity-organization, industry, and strategic group-in an interrelated way to inform complex identities, emerging from our data in both how firms talk about themselves as well as how they approach core activities. Organizations draw on industry and strategic group identities to inform their own identity, meaning some claims are shared while some are unique. Yet even unique claims are nested in a firm's affiliation with higher-level identities. Our analysis shows the importance of strategic group identity, as it serves to filter both organization and industry-level identities, shaping how organizations interpret the industry and ground their organizational identity claims. Within each strategic group, organizations differentiate their identities relative to group peers, not organizations in the other group. Organizations emphasize particular claims or interpret them differently, with the strategic group identity guiding these interpretations.

\subsection{Connecting nested levels of identity with strategy}

Paralleling the data on identities with that on competitive actions, observed through quantitative data on firm behaviors, we find identity claims at each level relate to specific actions in patterned ways: organizational identity relates to decisions on product offerings, industry identity relates to downstream actions; and strategic group identity relates to upstream strategy, firm boundaries, and expansion modes. We summarized these patterns in Table 1 (see also Appendix Figure S2). Note that 
strategic group identity serves as a key reference point as it filters organizations' choices in enacting industry identity and bounds their choices in enacting organizational identity.

\subsection{1 | Organizational identity and strategy}

We find organizations differentiate from strategic group peers in product offerings, including brands, breadth of mix, number of models, and price points; and find product decisions align with each organization's unique identity claims. Again, we see strategic group identity filtering the enactment of organizational identity claims. Rather than all organizations differentiating from one another, we see Assemblers differentiating from one another more than from Crafters, and vice versa, both in competitive actions and identity claims.

Within the Assemblers group, Fleetwood, Forest River, and Thor differ in the breadth of products they offer, although all Assemblers draw on the group's identity claims of competition and efficiency in their product offering strategy. Fleetwood produces only 24 models of type A and C motorhomes, making no towable products. This limited breadth aligns well with their identity focus on brand recognition and lean processes, allowing them to streamline production.

Forest River differentiates by focusing on high-volume, low-cost products, aligned with their value-oriented identity. Their six divisions produce nearly 200 models, emphasizing lower price points. Their high volumes allow them to reduce costs, using efficiency and acquisitions to increase product variety and boost sales. Thor, on the other hand, produces products across the entire spectrum of RV products and nearly all price points, noting in one of their videos that:

Thor Motor Coach is the \#1 motorhome brand in North America, producing nearly one out of every four motorhomes sold each year. Thor Motor Coach leads the RV industry in introducing cutting edge innovation and offering a variety of options to fit every customer's lifestyle and budget (2014).

Within those types of products, Thor's 11 subsidiaries produce nearly the same total number of products as Forest River, but fewer models in some categories. Thor distinguishes itself from other Assemblers as a rapid innovator, quickly introducing new models and dropping others.

Like Assemblers, Crafters differ in the breadth and variety of products they offer. However, the Crafter organizations draw on the group's identity claims of being quality and people focused in their product offerings. Crafters have few subsidiaries, keep close control over their operations, and typically offer just a single, flagship brand. Jayco differentiates from other Crafters in their intense emphasis on its identity as a family organization. Jayco has a relatively broad line including 38 models, mostly towables, letting them "build dreams" for families at each price point. As Derald Bontrager, President and founder's son, noted: "Yes, we're a family business. And we have included [customers, suppliers, and dealers] in our extended family. And that means we're all in this journey together. That's where we're different from most of the others" (RVB, 2012). Winnebago produces approximately the same number of models as Jayco, but emphasizes motorhomes, as consumers see their iconic brand as synonymous with this product. As their PR specialist notes, "In all of our marketing efforts, we are focusing on bringing [the] Winnebago [brand] to the forefront. [W] want people to see motorhome and immediately connect to Winnebago-no stop in between" (RVB, 2015). They recently diversified into towables, but this represents less than $10 \%$ of their business and was, according to industry insiders, more about obtaining a presence in Indiana. Their identity focuses on engineering and having a coherent style aligned with their iconic image. The other Crafters, Newmar and Tiffin, have very narrow product breadth, producing only Type A rigs and a small number of models. In alignment with their premium and supplier-oriented identity claims, Newmar specializes 
in products with high-end interiors developed through a close relationship between suppliers and sales and design staffs. This focus aligns well with their identity of being old-fashioned and premium - they just offer a few, high-quality products. Likewise, Tiffin offers few product lines, with only six class-A models; their narrow offerings allow them to differentiate through extreme levels of customer care and service. They offer the widest choice of chassis and can replace any part on any model. Their owner stresses customer connections saying, "The best way (to communicate with customers) is to talk on the telephone or eyeball to eyeball. You just have to hang in there with them. That's what we do." (RVB, 2014).

By examining identity as a driver of competitive actions, we can see the complex decisions these firms make based on balancing conformity with group-level identity claims, while also differentiating within the group using organizational identity claims. Our empirical results show that organizational identity is closely related to a firm's product offerings and ties into its branding and capabilities. To illustrate this, consider the contested market for Type A motorhomes, in which all seven firms participate. Fleetwood emphasizes its four brands and 19 models, with the most extensive product range from entry-level gas rigs up to $\$ 600 \mathrm{~K}+$ diesel pushers, enabling it to span the entire Type A market. Thor consolidated its offerings under a single brand in 2010, recently offering 11 models that change regularly, continually trying new innovations such as the ACE model and the Axis RUV aimed at soccer moms. This broad product line with its constantly updated components ties directly to Thor's claims being entrepreneurial, having "something for everyone," and being focused on market outcomes. Forest River offers two brands of Type A rigs, generally low cost, high value gas models. It does also sell the diesel Berkshire, which lists for $\$ 250 \mathrm{~K}$ but actually retails for well under $\$ 200 \mathrm{~K}$, due to dealer competition, a clear alignment with their claims of being a rivalrous, value-focused firm. Winnebago offers sister products under its two brands, for a total of 18 models, with some nameplates, such as the Brave and Adventurer, having been produced for decades, underlining their claim of an iconic brand. Rather than experimenting, Winnebago reengineers familiar rigs until they have something truly new to offer. Tiffin offers six models under the single Allegro brand but offers myriad options for chassis and other features. Newmar has one brand with 10 high-end models, including ones that are wheelchair accessible and that have exclusive steering and entertainment systems, co-developed with suppliers. Jayco produces five models under two brands-Jayco for the lower-end gas products and Entegra for high-end luxury models, letting them offer products to fulfill dreams for all families.

This overview of the Type A market illustrates how firms offer products that align with their organizational identities, which allow them to differentiate. It also shows that within their groups, they stake out territory that is distinct (e.g., producing a broad or narrow product line) and thus compete more with firms from the other group. For example, Jayco competes with Forest River on the low end and with Fleetwood on the high end; Winnebago competes with Thor across all types of motorhomes. The levels of identity affect how firms conform, differentiate, and compete.

\subsubsection{Industry identity and downstream strategy}

Organizations conform to the industry identity claim of relationship-focus as they all articulate the importance of dealer relationships. However, how firms manage their dealers differs in patterned ways, with their interpretation filtered through their strategic group identity. Assembler firms, while stating dealer relationships are important, are transactional and competitive in these relationships. A Forest River executive stated their dealer body was "the lifeline of our company" and noted that bringing in new dealers "brought new energy and volume to our company" [emphasis added] (RVB, 2010). Assemblers express the importance of dealers as the conduit of sales and 
encourage dealers to compete. This approach is consistent with the industry identity, which emphasizes relationships, but manifested through the Assembler's strategic group identity lens of competitiveness.

In contrast, through the lens of being quality-focused and collaborative, Crafters interpret this same industry identity as a mandate to emphasize personal, long-term relationships. Crafters choose dealers carefully, with fewer and more exclusive relationships, resulting in higher sales per dealer. Typifying a Crafter approach, Bob Tiffin says, "We don't have [dealers] stacked on top of each other...they have a good territory and a good placement of product and we try our best to support them better than anybody" (RVB, 2014). The difference between Assemblers and Crafters is further evidenced by dealer satisfaction ratings. Since 1996, the RV Dealers Association has bestowed annual awards based on a survey of manufacturers' warranties, responsiveness, quality, and relationships. Assemblers have rarely won this award, whereas Crafters Jayco, Tiffin, and Winnebago have won it every year.

Industry identity is thus enacted through the filter of strategic group identity, rather than directly, allowing organizations to maintain a position that is both legitimate from the industry point of view (i.e., dealer relationships are important) but also fits with other organizations in their strategic group, allowing conformity with differentiation.

\subsection{3 | Strategic group identity and strategy}

In terms of competitive actions, organizations conform within but differentiate between strategic groups in managing firm boundaries. We find evidence firms draw on the identity claims of their strategic group to inform vertical integration and entry mode decisions. Aligning with their strategic group identity focus on competition and efficiency, Assemblers focus on low cost production through outsourcing, divisional rivalries, and lean manufacturing. Assemblers rely on suppliers for innovation while also pressing them for lower prices. A Thor representative that we interviewed commented: "We're the experts at assembly_how the walls go up, where the pressure points are," but they "let the suppliers be the experts at everything else." He said Thor was "the Wal-Mart of the RV industry," following a low-cost, high-volume market position. Assemblers tend to have multiple divisions in the same product category and openly pit them against each other, with a decentralized structure. As Thor's president Bob Martin noted:

While Thor is a bigger company overall, we have really eight smaller entities that decide what they'll build on a daily basis. We don't dictate any of that here. They design their own products, and they compete. (RVB, 2014)

In keeping with this approach, we observed that Assemblers primarily expanded through acquisition, grafting new units onto their current structure, with Forest River and Thor having been created through acquisitions and Thor being the most active. Interestingly, Thor recently purchased Postle, a components manufacturer, but carefully stated that this was not a case of vertical integration since Postle would continue to be the "Wal-Mart of the aluminum industry" and supply all RV firms. CEO Martin commented, "I called many of my competitors in the industry and just let them know that our intent was to let Postle run, you know, business as usual [with] no big changes.... we're so decentralized, this is possible" (RVB, 2015). Fleetwood's parent is also an active acquirer, having purchased the Holiday Rambler and Monaco brands.

Thus, we see that Fleetwood, Forest River, and Thor draw on the Assembler group-level identity claims to inform their decisions on how and why they approach firm boundaries. Assemblers are more than a group of firms that pursue a cost-leadership strategy, as they may appear on the surface. 
Unlike the orthodox description of cost leaders, these firms are not insular but focus on the market. Through examining strategic group identity claims, we have a deeper understanding of why each firm claims to be competitive, cost-focused, and market-focused, and then implements their vertical and horizontal firm boundary strategies to align with these claims.

On the other hand, in terms of competitive actions, Crafters stress vertical integration and organic expansion, strategies that parallel their identity claims of being collaborative and focused on people and quality. Greater vertical integration allows for more customization, often with a focus on premium features, as well as superior customer service, as they can provide dealers with parts for older models. Tiffin and Winnebago are the most vertically integrated, creating most of their components in-house, although only Tiffin builds chassis. Unlike Assemblers, Crafters do not squeeze suppliers on price, but rather collaborate and develop proprietary technologies, such as Newmar's PowerGlide steering system created with Freightliner.

Unlike Assemblers, we observed that most Crafters are generally private organizations that expand organically, rarely through acquisitions, fitting with the group's collaborative and peoplefocused identity claims. Although Winnebago recently purchased Sunnybrook, this was motivated by the 2008-2009 economic downturn and allowed them to diversify into towables, and it has done so primarily organically and under its own nameplate. Likewise, Jayco acquired Travel Supreme in 2008, but morphed this entity into its own high-end motorized line, Entegra Coach. Neither Tiffin nor Newmar have an acquisition history, with Bob Tiffin noting his company has no pressing need for expansion and has a conservative approach:

The biggest problem is that some people (manufacturers) try to over-deal. We, on the other hand, never ever build a motorhome if we haven't got an order for it. We passed that rule here in 1979 and we have not wavered from it one minute and we never will. ... A family company, I think, is much more suitable for this low-volume industry ... especially the motorized segment. (RVB, 2014)

In sum, we see Jayco, Newmar, Tiffin, and Winnebago draw on the Crafter group-level identity claims to inform their decisions on how and why they approach and implement their firm boundary decisions. Again, by examining strategic group identity claims, we have a deeper understanding of why each of the Crafter firms all claim to be quality-focused and collaborative, and are not just "differentiators." They do consider market outcomes but are not overly responsive to market demands but rather are more driven by providing quality products made by talented employees to collaborate with their dedicated dealers and satisfy their loyal customers.

Thus, we find that strategic group identity aligns with organizations' vertical integration and expansion approaches, while also acting as a filter for their industry identity, keeping it in line with others but also creating boundaries for their enactment of their organizational identity.

\section{3 | Summary: nested levels of identity and strategy}

Our findings demonstrate how organizations draw on nested levels of identity to inform competitive actions. We find connections between industry identity and downstream strategies, between strategic group identity and firm boundaries, and between organization identity and product offerings. Furthermore, we find that strategic group identity influences how organizations interpret industry and organization level identity claims, as they take actions to both conform and differentiate. 


\section{I LINKING NESTED IDENTITIES AND STRATEGY: A CONCEPTUAL MODEL}

Combining our inductive qualitative analysis of identities at various levels with our analysis of quantitative data on each firm, we see the relationships of nested identity and of identity to strategy are not isolated from one another. Rather, each level of identity - organization, industry, and strategic group - guides managers to align strategies with identity, differentiating from or conforming to peers in their strategic group and industry (see also Figure S3 in the Appendix S3).

Importantly, strategic group identity acts not simply as a bridge connecting industry and organizational identity levels (Reger \& Huff, 1993), but also as a mediator, translating between the industry and organization levels. Organizational identity takes strategic group identity as the ground from which it must differentiate itself, but doing so in a way that does not alienate the strategic group. Likewise, the industry identity's focus on relationships is not directly enacted, but filtered through strategic group identity. While all organizations acknowledge and affirm the importance of relationships, they enact them according to their strategic group identity claims.

To unpack our model, we begin with industry identity and note that organizations must conform to maintain legitimacy (Deephouse, 1999). However, this conformity is enacted through the filter of strategic group identity, adapting industry identity claims to group-level imperatives. Thus, we see industry norms of behavior interpreted to align with strategic group identity. This suggests isomorphism at the industry level may, when examined at the strategic group level, be less monolithic than is often supposed. Strategic group identity and legitimization of action may mitigate or shift the focus of pressures for industry-wide conformity. Shifting to organizational identity, claims at this level do not act as a filter for higher-level identities, but rather aim to differentiate within the boundaries of strategic group identity.

Moving to links between identity and competitive actions, the organization level both elaborates on strategic group-level claims and provides differentiation through branding and product offerings. These choices appear to be tied to organizations' history and identity, allowing differentiation without challenging strategic group or industry identities. Assemblers can efficiently offer products in every segment under many brands with great variety (Thor), focus on select segments with wellpriced brands and many models (Forest River), or limit their product range (Fleetwood). Likewise, Crafters can be narrow (Tiffin) or broad (Winnebago) in their product offerings and emphasize branding, highlighting what is unique to the organization.

The industry identity relates most closely to downstream strategies, as dealers are deeply involved in the industry and influence industry norms. Unlike upstream suppliers, who may serve other industries, dealers are often invested in one industry. Dealers can represent many producers, regardless of strategic group, and so may influence competitive action across group boundaries. Since end-users primarily interact with the industry through dealers, it makes sense that a key part of industry identity would be valuing dealer relationships.

Strategic group identity does not simply interpret industry level identity claims but makes claims of its own. Members of each group conform somewhat to both the identity claims and the broad strategies of that group (Navis \& Glynn, 2010). Strategic group identity is most closely related to firm boundary decisions and expansion strategies, which tend to be difficult to change due to significant investments. For example, it would be challenging for Assemblers to vertically integrate and develop the internal expertise common among Crafters. Likewise, it would be difficult for Crafters to acquire and integrate new organizations and brands, an expansion strategy embraced by Assemblers. We cannot address causality, but group members do share both identity claims and firm boundaries and expansion strategies that are consistent and aligned. 
In sum, our model suggests organizations draw on identities in combination and that no single level of identity dominates, although strategic group identity has the broadest effect. Organizations can thus share identity claims across strategic groups and industry, maintaining legitimacy, but differentiate by engaging in actions rooted in their organizational identities.

\section{6 | DISCUSSION}

In this study, we explored how identity interacts at multiple levels and affects strategy, developing a model of how nested identities interact and connect with firms' competitive actions. We explored this in an industry that is stable and mature, with limited variance in firm attributes and value chains, to control for typical economic drivers to better isolate the cognitive effects of identity on competitive actions. Economic-based theories would suggest, given similar economic drivers, organizations should engage in similar actions and strategies. However, our study illustrates that given similar economic drivers, cognitive drivers of competitive action, namely identity, become evident and influence both conformity and differentiation. Our findings demonstrate how industry identity delineates the players and norms, how strategic group identity addresses the approach to competition, and how organizational identity relates to product-level actions. Thus, we find connections between the levels of identity and between identity levels and competitive actions, which have implications for theories of cognition and competition.

However, we must acknowledge the caveat that as our context may be somewhat unique. The RV industry is technologically mature, has a relatively small number of players, is largely geographically concentrated, and is rather insular. This allows for considerable stability in identities at all levels. In terms of the specific competitive actions, our mapping of product offerings to organizational identity could be an artifact of a consumer-goods sector and our connection between industry identity and downstream relationships may be driven by a large number of distributors without exclusive links to manufacturers. That said, we do believe our results are generalizable, as other sectors share these characteristics and therefore offer the following conceptual framework developed from our empirical results.

\subsection{The nested levels of identity}

Although prior research examined how organizations manage and resolve tensions between multiple identities within the same organization, we lack insight into how organizations manage and resolve tensions between identities that reside at multiple levels (Moss et al., 2011). Furthermore, some existing theory discusses identity at various levels, yet little work has explored how these levels may interact (Foreman \& Whetten, 2002). Ashforth et al. (2011) conceptually explore the relationship of different levels and suggest sameness at the group level allows uniqueness at the individual level, and this sameness at the group level is "simply the water they all swim in" (1150). Our examination of the RV industry both supports and contests this suggestion. Organizations seem to treat the industry level as a background against which they pursue uniqueness. But, the strategic group level may be even more salient as it filters how organizations enact the industry level and interpret the organizational level.

Likewise, our work supports and extends work by Porac et al. (1989), as we find managers develop shared mental models of appropriate strategies accepted as norms and connected to an industry's identity. Much like Porac's Scottish knitwear firms, the RV sector is insular and homogenous, with strongly shared views on the industry and firms enacting strategies to fit these views and be legitimated (Porac et al., 1989). However, our work extends this as we consider multiple strategic groups and thus how strategic group identity affects the interpretation and enactment of industry 
identity. Our work then builds on this prior literature to suggest organizations enact strategies aligning with industry identity to remain legitimate (Dhalla \& Oliver, 2013; Hsu \& Hannan, 2005; Navis \& Glynn, 2010) but do so in a way that also maintains alignment with their strategic group identity. This provides insights into how organizations manage the constant tension between needs to conform and differentiate (Deephouse, 1999).

Our findings in the RV industry highlight how strategic group identity is a filter through which organizations can enact industry identity and a context to interpret organizational identity. Our study corroborates research demonstrating strategic groups are cognitively determined and meaningful in how organizations position themselves (Reger \& Huff, 1993; Short et al., 2007), and provides empirical support for research suggesting geographically proximate and insular strategic groups competing across markets have stronger identities (Peteraf \& Shanley, 1997). We find strategic group identities are used as filters not to change the industry structure, but to maintain it and allow for differentiation and conformity. Our findings also support the traditional principle that multiple dominant strategies can co-exist within an industry, such as cost leadership and differentiation (Fisher, 1997; Porter, 1980), but we find this manifesting at the group, rather than organization, level. In more formal terms, we present:

Proposition 1 The identity claims of the strategic group to which a firm belongs filter how the firm interprets and conforms to the industry identity. Likewise, strategic group identity claims guide how the firm differentiates its own organizational identity from group and industry peers.

\subsection{Links between identity levels and competitive actions}

Previous research suggests links between identity and strategy, primarily examining how an organization's leadership may manage tensions between multiple identities to resolve or avoid identity-based conflicts arising from organizational members' affiliation with one identity over another (e.g., Ashforth \& Reingen, 2014). However, these studies investigate connections between identity and action within single organizations, not between levels of identity or among multiple organizations. We do have some prior work arguing that industry, organizational, and strategic group identities each affect organizational performance (Short et al., 2007), but these levels are examined independently. We integrate identity at these levels and consider how they drive certain competitive actions relevant in our context, such as branding and differentiation from competitors. Fiol (2001) proposed organizational identity can provide organizations with a competitive advantage, but suggested this might be difficult to sustain. Our model shows organizations do draw from their organizational identity to develop business-level strategies aimed at building a competitive advantage, specifically in product offerings. As organizational identity focuses on differentiation, embodied in product lines, it shows customers in a concrete way "who the firm is" and strives to create a market niche. More generally, this aligns with the notion that organizational identity can underpin creation and maintenance of brand differentiation and that cognition and capabilities co-evolve (Eggers \& Kaplan, 2013). Thus, we suggest:

Proposition 2 A firm draws on its organizational level identity for business-level strategic decisions as it uses this to interpret how to differentiate and take competitive actions to gain an advantage over rivals.

Connecting industry identity with downstream strategies in our research context suggests the purpose of a strong industry identity is to reinforce its position and message among outside 
stakeholders to ensure its survival and growth (Dhalla \& Oliver, 2013). This involves how to present, market, and manage the image of the industry to outsiders, including customers. From a firm standpoint, this means managing downstream relationships in a manner consistent with others in the industry to indicate cohesion and signal legitimacy. It also involves cooperating with others in the industry to support broader initiatives important to customers and industry growth. Thus, to remain legitimate in its industry, a firm must conform in terms of competitive actions that are associated with the industry level identity claims. So, we posit:

\section{Proposition 3 A firm draws on industry level identity to interpret and implement corporate-level downstream competitive actions relating to conformance to remain legitimate relative to industry peers.}

Scholars have linked organizational identity with the corporate-level strategic decision of firm boundary choices such that identity provides a mental model to drive coherent actions (Santos \& Eisenhardt, 2005). We found evidence of this, but at the strategic group level rather than the organizational level. We thus posit firm boundary and acquisition strategies are driven by strategic group identity, finding links between high vertical integration and organic expansion and between outsourcing and acquisitions. This somewhat fits with classic Porterian strategies of cost leadership and differentiation, as Fisher (1997) matched these with outsourcing and internal production, respectively. Cost leadership involves efficiency, consistent with outsourcing, whereas differentiation involves customization, consistent with vertical integration. However, strategic group identities appear broader than these classic economic approaches since we found that both groups emphasize internal processes and market outcomes, albeit aiming for different goals. Our Assemblers were not fully insular and internally focused, but rather scoured the market for firms to acquire and kept these new brands decentralized and differentiated. Likewise, our Crafters did focus on being flexible to satisfy customers with quality products, but were also conservative and grew organically, not as classically "market responsive" as true differentiators.

More generally, finding coherence between boundary and expansion actions is supported by research on coherence, strategic fit, and business models (Siggelkow, 2001; Teece et al., 1994). We found that strategic group identity influenced a wide array of competitive actions and thus appears to be the level providing this coherence to firms' actions. Thus, we offer:

\section{Proposition 4 A firm draws on its strategic group identity to inform corporate-level strategic decisions related to firm boundaries and entry mode choices to conform with group peers.}

Furthermore, providing a holistic view of multiple levels of identity, our study deepens our understanding of multimarket competition (MMC), as many of our firms compete in multiple markets. Particularly in an industry such as ours, which is small and mature with well-known players who interact often, we expected mutual forbearance, in which organizations recognize their interdependence and act to minimize retaliation (Chen \& Miller, 2012). Instead, we found vigorous competition, especially among Assemblers, suggesting other factors are at work. Looking at strategic group identity, competition and market-focus are core claims of Assemblers, but not of Crafters, making this group more likely to vigorously compete across product markets (e.g., Forest River and Thor in towables). However, the rivalry does not seriously escalate nor are Crafters drawn in, as extant theory would predict (Gimeno \& Woo, 1996). Thus, our model supports recent developments in MMC theory suggesting rivalrous and relational competitive behaviors can be driven by strategic group identity. At the same time, organizational identity drives product offerings and branding, also 
influencing which competitors firms choose to target and the overall level of competition (Livengood \& Reger, 2010).

Finally, our work builds on and extends work in cognitive drivers of strategy, suggesting that firms leverage different levels of identity to interpret and react to competitors' actions. Prior research has demonstrated the importance of integrating a cognitive perspective into why firms react to competitors as they do (Marcel, Barr, \& Duhaime, 2011). For example, we know the more "competitive acumen" a firm has, or the capability to accurately perceive a competitor firm's strategic concerns and actions, the better the firm will develop response strategies (Tsai, Su, \& Chen, 2011). As executives are able to draw on more accurate mental models and develop competitive acumen at the strategic group-level (Pegels, Song, \& Yang, 2000), our study suggests that the strategic-group level of identity could serve as a mediator or moderator of managers' perceptions of competitors' actions, and thus affect competitive acumen. By bringing nested levels of identity into the process by which managers subjectively interpret and react to the competitive environment, we deepen our understanding of why firms operating within the same industry enact heterogeneous but patterned competitive actions or why firms engage in relational competition (Chen \& Miller, 2015).

\section{7 | CONCLUSION}

Our findings and model indicate the importance of understanding multiple levels of identity and how they relate to competitive actions. In addition to the theoretical contributions and implications mentioned above, our work also has implications for managers. By understanding how different levels of identity inform different competitive actions, managers can set more cohesive strategies, drawing on the identity claims at each level: organizational for product offerings, industry for downstream relationships, and strategic group for firm boundaries and expansion modes. Importantly, our research demonstrates how strategic group identity filters both industry and organization level identities. We do not suggest causal relationships between identity and strategy, nor that managers can control identities. Rather, we stress the importance of managers' understanding the cognitive lenses that affect competitive actions.

Like all studies, ours has limitations that provide opportunities for additional work. As an indepth embedded case study, our findings are rooted in our context - a single industry - and thus the specific competitive actions that we studied represent relevant actions in that setting. In other settings, different competitive actions may be more relevant and the association with identity level may be more complex. Also, our connections between strategic group identity and firm boundaries may be less applicable in service sectors. Thus, applying our model to a variety of other sectors to probe its boundary conditions would be fruitful. Due to the steady nature of identity in this industry, we treat identity solely as a set of characteristics, not as a process. As such, our data cannot address iterative relationships between identity, competitive actions, and strategy. Moreover, although we revealed relationships, we were not able to investigate the mechanisms underlying the development of identities and actions. We urge future research to uncover these mechanisms to understand how they develop and how they may be managed.

Additionally, future work could build on existing theory regarding the management of tensions between multiple identities within organizations (e.g., Moss et al., 2011), to examine the nature of how organizations manage different levels of identity to avoid "intractable conflicts" (Fiol et al., 2009) and what effect these have on the organization's strategic actions. That is, work could also explore whether and how executives can manage the different nested levels of identity to avoid and resolve identity-based conflicts. 
The literatures of identity and strategy have grown rich and varied, helping us to understand how and why managers do what they do, and which strategies are successful. We believe this paper adds to both literatures by connecting them at the organization, industry, and strategic group levels, deepening our understanding of how identity relates to strategy and hope our study stimulates further conversations between these literatures.

\section{ACKNOWLEDGEMENTS}

All authors contributed equally and are listed alphabetically. We would like to thank Editor Pam Barr and the anonymous reviewers for their encouragement and developmental criticism that improved this manuscript; any remaining errors are our own. We appreciate the involvement of the RV industry members, and the support of Jennifer Howard-Grenville, Aldas Kriauciunas, and Miguel Rivera-Santos.

\section{REFERENCES}

Albert, S., Ashforth, B. E., \& Dutton, J. E. (2000). Organizational identity and identification: Charting new waters and building new bridges. Academy of Management Journal, 25(1), 13-18.

Albert, S., \& Whetten, D. (1985). Organizational identity. Research in Organizational Behavior, 7, 263-295.

Ashforth, B., Rogers, K., \& Corley, K. (2011). Identity in organizations: Exploring cross-level dynamics. Organization Science, 22(5), 1144-1156.

Ashforth, B. E., \& Reingen, P. H. (2014). Functions of dysfunction managing the dynamics of an organizational duality in a natural food cooperative. Administrative Science Quarterly, 59(3), 434-516.

Barney, J. B. (1991). Firm resources and sustained competitive advantage. Journal of Management, 17(1), 99-120.

Chen, M., \& Miller, D. (2012). Competitive dynamics: Themes, trends, and a prospective research platform. The Academy of Management Annals, 6(1), 135-210.

Chen, M. J., \& Miller, D. (2015). Reconceptualizing competitive dynamics: A multidimensional framework. Strategic Management Journal, 36(5), 758-775.

Clegg, S. R., Rhodes, C., \& Kornberger, M. (2007). Desperately seeking legitimacy: Organizational identity and emerging industries. Organization Studies, 28(4), 495-513.

Deephouse, D. (1999). To be different, or to be the same? It's a question (and theory) of strategic balance. Strategic Management Journal, 20(2), 147-166.

Dhalla, R., \& Oliver, C. (2013). Industry identity in an oligopolistic market and firms' responses to institutional pressures. Organization Studies, 34(12), 1803-1834.

Eggers, J., \& Kaplan, S. (2013). Cognition and capabilities: A multi-level perspective. The Academy of Management Annals, 7(1), 295-340.

Eisenhardt, K., \& Graebner, M. (2007). Theory building from cases: Opportunities and challenges. Academy of Management Journal, $50(1), 25-32$.

Fiol, C. M. (2001). Revisiting an identity-based view of sustainable competitive advantage. Journal of Management, 27(6), 691-699.

Fiol, C. M., Pratt, M. G., \& O'Connor, E. J. (2009). Managing intractable identity conflicts. Academy of Management Review, 34(1), 32-55.

Fisher, M. L. (1997). What is the right supply chain for your product? Harvard Business Review, 75, 105-116.

Foreman, P., \& Whetten, D. A. (2002). Members' identification with multiple-identity organizations. Organization Science, 13(6), $618-635$.

Gibbert, M., Ruigrok, W., \& Wicki, B. (2008). Research notes and commentaries what passes as a rigorous case study. Strategic Management Journal, 29(13), 1465-1474.

Gimeno, J., \& Woo, C. Y. (1996). Hypercompetition in a multimarket environment: The role of strategic similarity and multimarket contact in competitive de-escalation. Organization Science, 7(3), 322-341.

Gioia, D. A., Price, K. N., Hamilton, A. L., \& Thomas, J. B. (2010). Forging an identity: An insider-outsider study of processes involved in the formation of organizational identity. Administrative Science Quarterly, 55(1), 1-46.

Glynn, M. A. (2000). When cymbals become symbols: Conflict over organizational identity within a symphony orchestra. Organization Science, 11(3), 285-298.

Hsu, G., \& Hannan, M. T. (2005). Identities, genres, and organizational forms. Organization Science, 16(5), 474-490.

Ireland, R. D., Hitt, M. A., Camp, S. M., \& Sexton, D. L. (2001). Entrepreneurship and strategic management actions to create firm wealth. Academy of Management Review, 15(1), 49-63. 
Kiss, A. N., \& Barr, P. S. (2015). New venture strategic adaptation: The interplay of belief structures and industry context. Strategic Management Journal, 36(8), 1245-1263.

Lieberman, M. B., \& Asaba, S. (2006). Why do firms imitate each other? Academy of Management Review, 31(2), 366-385.

Livengood, R. S., \& Reger, R. K. (2010). That's our turf! Identity domains and competitive dynamics. Academy of Management Review, 35(1), 48-66.

Marcel, J. J., Barr, P. S., \& Duhaime, I. M. (2011). The influence of executive cognition on competitive dynamics. Strategic Management Journal, 32(2), 115-138.

Miles, M., \& Huberman, A. (1994). Qualitative data analysis: An expanded sourcebook. Thousand Oaks, CA: Sage.

Moss, T. W., Short, J. C., Payne, G. T., \& Lumpkin, G. T. (2011). Dual identities in social ventures: An exploratory study. Entrepreneurship Theory and Practice, 35(4), 805-830.

Nadkarni, S., \& Barr, P. S. (2008). Environmental context, managerial cognition, and competitive action: An integrated view. Strategic Management Journal, 29(13), 1395-1427.

Narayanan, V. K., Zane, L. J., \& Kemmerer, B. (2011). The cognitive perspective in strategy: An integrative review. Journal of Management, 37(1), 305-351.

Navis, C., \& Glynn, M. A. (2010). How new market categories emerge: Temporal dynamics of legitimacy, identity, and entrepreneurship in satellite radio, 1990-2005. Administrative Science Quarterly, 55(3), 439-471.

Patvardhan, S. D., Gioia, D. A., \& Hamilton, A. L. (2015). Weathering a meta-level identity crisis: Forging a coherent collective identity for an emerging field. Academy of Management Journal, 58(2), 405-435.

Pegels, C. C., Song, Y. I., \& Yang, B. (2000). Management heterogeneity, competitive interaction groups, and firm performance. Strategic Management Journal, 21(9), 911-923.

Peteraf, M., \& Shanley, M. (1997). Getting to know you: A theory of strategic group identity. Strategic Management Journal, 18(1), $165-186$.

Porac, J. F., Thomas, H., \& Baden-Fuller, C. (1989). Competitive groups as cognitive communities: The case of Scottish knitwear manufacturers. Journal of Management Studies, 26(4), 397-416.

Porac, J. F., Thomas, H., \& Baden-Fuller, C. (2011). Competitive groups as cognitive communities: The case of Scottish knitwear manufacturers revisited. Journal of Management Studies, 48(3), 646-664.

Porter, M. (1980). Competitive strategy: Techniques for analyzing industries and competitors. New York, NY: Free Press.

Porter, M. (1991). Toward a dynamic theory of strategy. Strategic Management Journal, 12, 95-117.

Reger, R. S., \& Huff, A. S. (1993). Strategic groups: A cognitive perspective. Strategic Management Journal, 14, $103-123$.

Santos, F. M., \& Eisenhardt, K. M. (2005). Organizational boundaries and theories of organization. Organization Science, 16(5), 491-508.

Short, J. C., Ketchen Jr., D. J., Palmer, T. B., \& Hult, G. T. M. (2007). Firm, strategic group, and industry influences on performance. Strategic Management Journal, 28, 147-167.

Siggelkow, N. (2001). Change in the presence of fit: The rise, the fall, and the renaissance of Liz Claiborne. Academy of Management Journal, 44(4), 838-857.

Teece, D. J., Rumelt, R., Dosi, G., \& Winter, S. (1994). Understanding corporate coherence: Theory and evidence. Journal of Economic Behavior and Organization, 23(1), 1-30.

Tsai, W., Su, K. H., \& Chen, M. J. (2011). Seeing through the eyes of a rival: Competitor acumen based on rival-centric perceptions. Academy of Management Journal, 54(4), 761-778.

Yin, R. K. (2003). Case study research design and methods, Applied Social Research Methods series, Vol. 5 (3rd ed.). Thousand Oaks, CA: Sage.

\section{SUPPORTING INFORMATION}

Additional Supporting Information may be found online in the supporting information tab for this article.

How to cite this article: Irwin J, Lahneman B, Parmigiani A. Nested identities as cognitive drivers of strategy. Strat Mgmt J. 2017;1-26. https://doi.org/10.1002/smj.2735 